\title{
V . 土木建設分野における環境パフォーマンス評価の適用のあり方 STUDY ON THE ENVIRONMENTAL PERFORMANCE EVALUATION IN THE CONSTRUCTION INDUSTRY
}

土木学会地球環境委員会 環境パフォーマリス評価研究小委員会

相越 宏*

Hiromu AIKOSHI*

ABSTRUCT ; The Environmental Performance Evaluation (EPE) which was published in 1999 as International Standard ISO14031 is considered to be one of the effective measures to evaluate the organization's Environmental Management System(EMS). There are two types of indicators in the EPE. One is the Operational Performance Indicator(OPI), the other is the Management Performance Indicator(MPI). This paper presents the study of OPI and MPI in case of the construction companies.

KEYWORDS ; Environmental Performance Evaluation, Environmental Management System, Environmental Performance Indicator

\section{1. はじめに}

組織は、その活動、製品、サービスが環境に与える影響を明確にし、これらの環境側面を適切に管理する ことでシステムを維持している。環境パフォーマンス評価（E P E ）はその改善のための内部プロセスとツ 一ルであり、組織が設定したマネジメント基準にパフォーマンスが整合しているかどうかを見るためのもの である。そのため、環境マネジメントシステム( E M S )を有する組織では E P E 組織の環境目的や方針の 達成評価に使用することができる。

評価の指標には、下図の通り、環境パフォーマンス指標（E P I ）及び環境状態指標（E C I ）の 2 種類 を規定し、さらにE P I はマネージメントパフォーマンス指標（MP I ）及びオペレーショナルパフォーマ ンス指標（OP I ）の 2 種類に分けられる。

MP I は、組織の目的や方針の達成度合いなどシステム全体を評価するソフトの分野の指標といえる。一 方ＯPＩは、材料、エネルギー排出物など組織の事業活動のインプット及びアウトプットに関するものを評 価するハードな分野の指標といえる。
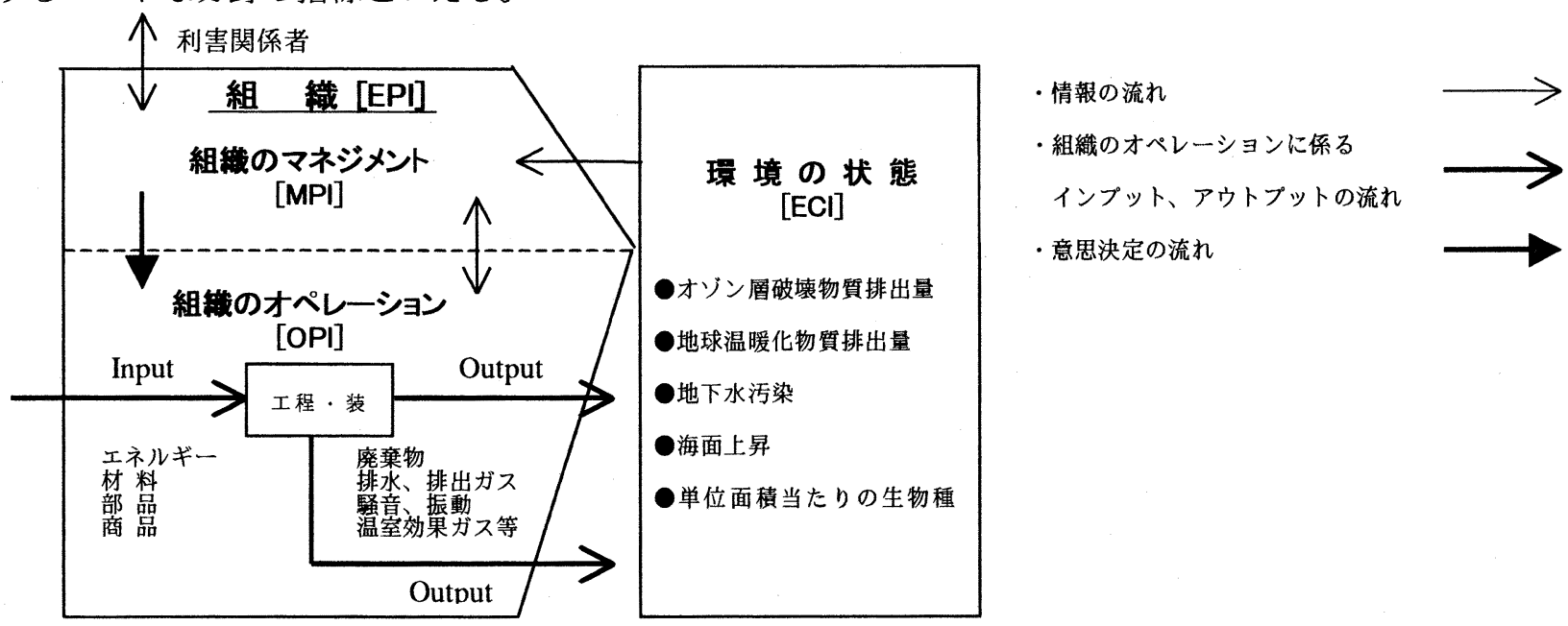

図 1 環境パフォーマンス評価の概念図

*佐藤工業株式会社 SATO KOGYO CO.,LTD 
MP I 及びO P I の対象領域は、組織の経営者が環境パフォーマンスの状態を評価し、必要に応じて改善 していく手助けとなるためのものであるから、いかなる組織単位つまり作業所とそれを所轄する支店とに適 用可能と考えられる。適用範囲は、組織の規模や事業形態に応じてを設定すればよいが、支店が一過性で施 工条件の異なる作業所で構成されていることを考慮すると、システムの管理上MP I およびOP I を支店と いう組織単位に適用させた方が望ましい。

\section{2.土木建設分野における環境パフォーマンス評価}

2. 1 MP I の事例

MP I は，経営層のための指標であり、システムを継続的に改善していく上では経営層がいかに関与する か, とりわけ最高経営層の関与が極めて重要な鍵となる。IS014001 の要求事項をみると, 最高経営層とい う言葉が使用されている事項が 3 つるが, 中でも「4.6 経営層による見直し」は, システムを評価し継 続的改善に慗げていくためのもので，その比重は非常に大きい。

IS014001 及びそのガイドライン IS014004 での見直しに係る記述は，以下のとおりである。

\begin{tabular}{|c|c|}
\hline IS014001 & 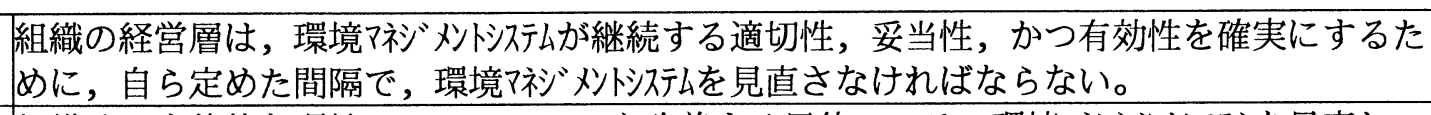 \\
\hline IS014004 & $\begin{array}{l}\text { 組織は，全休的な環境パフォーマンスを改善する目的で，その環境マ祙メ゙トシスデを見直し， } \\
\text { 継続的に改善することが望ましい。 }\end{array}$ \\
\hline
\end{tabular}

なお，IS014001 では上記の文の後で，経営層が評価を実施できるように必要な情報を確実に収集するこ とを求めている。ここで表現されている情報が，すなわち MPI に相当すると考えられる。

IS014001 に即したシステムを構築し認証取得している先進企業 4 社では, 経営層による見直しについて, 規格で嵒われている「適切性」「妥当性」及び「有効性」の3つを評価軸として取り上げ，それらの中味を 定義付けするとともに，各々に対応した MPI を設定している。

\begin{tabular}{|c|c|}
\hline 定義付け & $\begin{array}{l}\text { ·「適切性」については, 総じて, 規格要求事項の満足度としている。 } \\
\text { ・「妥当性」については, 針, 目的・目標が妥当かどうかを軸にしている。 } \\
\text { ・「有効性」については, システムが機能しているかどうかを軸にしている。 }\end{array}$ \\
\hline
\end{tabular}

なお，各社に共通する指標で，コミュニケーションの件数や不適合件数などは相互比較できるが，その 結果のみで各社のパフォーマンスの優劣やシステムレベルを判定することは困難である。それは, 目標とす るパフォーマンス基準が各社で異なるためである。したがって，比較に当たっては，指標の数值のみならず 各社のパフォーマンス基準等を含めた総合的な分析が必要と考えられる。

\section{2 OPIの事例}

IS014001 では，組織の環境方針，組織の活動，製品又はサービスに係わる環境側面，及びその環境影響 などを考慮して環境目的・目標を設定することを求めている。この過程において, 環境側面の洗い出しや環 境影響評価が行われるが，その際，事業活動を細分化するプロセス分析や投入行為・排出行為を分析するイ ンプット・アウトプット分析が実施される。これらの分析は，組織によって選択しかつ設定された種々の指 標をもとに実施されるが，それが OPI に相当すると考えられる。さらに，EMS 構築後にあっては，OPI は詳 細なパフォーマンスの測定及び評価のための指標として使用され,より具体的には, EMS で設定された下記 の(1)〜6環境目的や目標の達成度等を測るツールとして使用される。

(1) 公害対策 (大気・水質・騒音・振動・土壌・悪臬・地盤沈下) に係るもの

(2) 副産物・廃棄物に係るもの

(3) 環境保全に優れた資材の使用に係るもの 
(4) 間接部門における環境保全に係るもの

(5) 自然環境の保全に係るもの（開発における緑化率など）

６～環境負荷の少ない技術開発に係るもの（技術開発の数，技術の性能など）

\section{3 E C I の事例}

ECI は環境側の指標であり, 地方, 地域, 国内又は地球規模の環境状態についての情報を提供する指標 である。具体的には，大気・水・土㗒・自然・生態系・人間などが対象となり，個々の組織が扱うというよ りも，主として政府機関やNGO，科学機関や研究機関が取り扱う対象である。したがって，ビジネスを旨と する組織は，多くの場合，これらの機関が発表するECI を活用する立場となる。

しかし，土木建設分野に携わる組織は，製造業など他の産業組織と異なり，直接的に環境に手を加える という特徵を有しており，ECI との関わりが極めて大きいといえる。中でも実際のオペレーションの要であ る施工現場においては，地域との関わり合いが密接であるため，施工あるいはその前提となる計画・設計を 実施するに当たっては，予めその地域固有の社会環境なども考慮することが要求される。

\section{3．事業部門別の環境パフォーマンス評価の現状と課題}

環境パフォーマンス評価は、環境に影響を与える事業活動（環境側面）のすべてがその対象になり得る が、その中でも環境方針や著しい環境側面から設定される環境目的・目標については、定期的な見直しの際 に環境パフォーマンス評価を必らず実施することから、環境目的・目標の評価について本委員会の会員企業 の内、ISO14001 を既に認証取得している企業の事例を調査した。

調査の結果、環境目的・目標のパフォーマンス評価の主体は、組織の経営層（施工部門である支店単位の 認証取得の場合には支店長、設計部門や研究・開発部門の取得の場合はその部門長)、又は部門毎に設定され ている環境管理責任者となっている。

なお、環境パフォーマンス評価は、事業部門毎にパフォーマンス評価の内容が異なることが想定される ことから、企画·設計部門および施工部門の 2 部門に分けて評価方法、評価事例、今後の課題等について整 理した。

\section{1 企画·設計部門における環境パフォーマンス評価とは}

土木建設分野の場合、企画設計は企業者が行うことが一般化されており、その事業が公共的施設であるた め、主に政府及び自治体または前者によって創立された特殊法人等の公共体においてなされている。ただし、 その作業の多くが技術コンサルタント会社に委託されており、政策判断の重要な情報の作成という点でこの コンサルタント会社も当事者となる。

企画・設計は、多くの場合、コスト優先主義で行われており、環境負荷への配慮がなされている例は少な いのが現状である。しかし、設計対象となる構造物からの環境負荷は、その大部分を設計段階においていか に環境保全に配慮するかに負っているともいえる。従って、ある企業全体の環境負荷を継続的に削減してい くためには企画・設計段階において、その後の施工、運用・管理の段階での環境負荷を小さくするように対 応することが重要であり、そのような設計段階での対応を環境パフォーマンスとして評価していくことが求 められている。具体的な環境目的及び評価方法としては、次のようなものがあった。

\begin{tabular}{|c|c|}
\hline $\mathrm{A}$ 社 & $\begin{array}{l}\text { 省エネルギー }\left(\mathrm{CO}_{2} \text { 排出量削減)、故障・事故時の污染物拡散防止対策、環境污染排出物質の污 }\right. \\
\text { 染拡散防止など。 }\end{array}$ \\
\hline B 社 & 環境法規制等の遵守、環境配慮設計など。チエツクシート（配慮項目 150 項目以上）にて評価。 \\
\hline C社 & 企画、意匠、構造、設備等の部門毎に定められた数 \\
\hline
\end{tabular}


事業者にとって、環境パフォーマンスを向上させるような設計は、事業費（コスト）そのもののアップ につながる可能性が高い。このため、このような新たなコスト負担を強いるような企画・設計をトータルな 環境負荷の削減という観点から適正に評価していく方法を、発注者・受注者双方の協力で開発していくこと が望まれる。建設省では、地球温暖化防止への取り組みとして、CO2 排出量を定量的に把握したり、廃棄 物処理費用などの外部コストを考慮することでトータルの事業費の削減を可能とするような事業のコスト評 価方法について研究を実施しており、早期の成果が望まれる。

\section{2 施工部門における環境パフォーマンス評価とは}

企画・設計者である企業者から施工を請け負う施工部門は現実に建設現場において建設作業を行う部 門であることから、環境パフォーマンスとしては主にオペレイショナル・パフォーマンスが問われる。

今回実態調查した 7 社の内、 5 社以上が環境目的として設定している項目は以下の通りであり「公害対 策に係わるもの」及び「副産物·廃棄物に係るもの」が多く見られた。

(1) 工事騒音の抑制

(2) 工事振動の抑制

(3) 水質污濁の防止

(4) 建設混合廃棄物の発生量の削減

(5) 熱帯材型枠使用量の削減

評価指標の具体的な事例を見てみると、各企業が環境管理のどこに重点を置いて環境目的・目標を達成し ようとしているのかが分かる。その重点の置き方は概的次の 3 つに分けることができる。

\begin{tabular}{|l|l|}
\hline \multicolumn{1}{|c|}{ 指標のタイプ } & \multicolumn{1}{|c|}{ 工事騒音の場合 } \\
\hline (1) 管理基準順守型 & 法定規準值以内 $(\bigcirc \bigcirc \%$ 低減) \\
\hline (2) 結果重視型 & 苦情件数（前年比○○\%削減） \\
\hline (3) 対策重視型 & 低騒音型機械使用率 $(\bigcirc \bigcirc \%$ 上) \\
\hline
\end{tabular}

また、苦情件数が工事規模によって異なることを考慮して、工事出来高当りの苦情件数としている企業 もあるし、結果重視型と対策重視型の 2 つで評価しようとしている企業も見られた。

「水質污濁の防止」では、法定か自主かは問わず管理基準順守型が大部分であるが、対策重視型の「污 水流出防止対策実施作業所数」を指標としている例も見られた。

以上のように、一連の環境管理のどの部分に重点を置くかは、各企業の考え方によって異なっている。 しかし、環境目的の項目毎にその指標にはいろいろな工夫が考えられ、多様な組合せがあっても良いと思わ れる。

そこで、実際に使用されている指標が環境マネジメントのねらいに合致しているかどうかについても、各 企業に現時点での自己評価をしてもらった（表 1 参照）。

自己評価の結果、各企業の意見で共通していることは、現在用いている指標は、環境目的・目標の達成度 の測定が容易であると回答している例が多いことである。すなわち、測定が容易かどうかが指標採用の重要 な判断基準になっていることがわかる。次に、環境目的・目標の達成度が正確に把握できるか否かという点 については、指標の “モノサシ”としての数值は正確に測定できても、環境目的・目標の達成度が正しく測 れるかという点になると若干疑問が残るという自己評価をしている例が半数近く見られる。さらに、対策立 案に有効か否かについては、環境影響に関する対策と成果が直接的に結びつきにくいこともあり、実際の局 面では苦慮しているのが現状である。

以上のことから、単純に 1 つの指標だけでなく、いくつかの指標を用いて総合的に判断できるような工 夫が必要であろう。このことは、環境祙羽恼不么の基本的なねらいである環境保全活動の継続的な改善に 
つながり、シ人行を維持していく上で是非とも必要な考え方である。現時点では指標の事例も少なく、それぞ れに対する自己評価も一定の解釈が得られるほどの多くの意見が寄せられた訳ではないが、各企業の環境パ フォーマンス評価の事例とそれぞれの特徵を参考にして、今後の環境パフォーマンスの改善に活かしていく ことが重要であろう。

表 1 評価指標の設定についての自己評価事例

\begin{tabular}{|c|c|c|c|c|c|c|c|}
\hline & \multirow{3}{*}{ 目 } & \multirow{3}{*}{$\begin{array}{c}\text { 目 標 } \\
\text { (指標) }\end{array}$} & \multicolumn{5}{|c|}{ 指 標 の 特 改 } \\
\hline & & & \multicolumn{2}{|c|}{ 達成度 } & \multirow{2}{*}{$\begin{array}{l}\text { 有 } \\
\text { 効 } \\
\text { 性 }\end{array}$} & \multirow[b]{2}{*}{ コメント } & \multirow[b]{2}{*}{$\begin{array}{l}\text { 総合 } \\
\text { 評価 }\end{array}$} \\
\hline & & & $\begin{array}{l}\text { 容 } \\
\text { 易 }\end{array}$ & $\begin{array}{l}\text { 正 } \\
\text { 確 }\end{array}$ & & & \\
\hline 1 & $\begin{array}{l}\text { コリクリート・アスコン塊 } \\
\text { のリサ仿ル率向上 }\end{array}$ & $\begin{array}{l}\text { 然仍㻭を前年比 } \bigcirc \bigcirc \% \\
\text { UP (再利用/排出量) }\end{array}$ & 0 & $\triangle$ & $\triangle$ & $\begin{array}{l}\text { 把握しやすい指標 } \\
\text { 目標の達成は、中間処理場の能 } \\
\text { 力次第、中長期的目標が不明 }\end{array}$ & $\triangle$ \\
\hline 2 & $\begin{array}{l}\text { 建設発生土のリサ } \\
\text { 仍率向上 }\end{array}$ & $\begin{array}{l}\text { 枓仿ル率を前年比○○\% } \\
\text { UP }\end{array}$ & 0 & $\triangle$ & $\triangle$ & 同上 & $\mathrm{O}$ \\
\hline 3 & $\begin{array}{l}\text { 建設混合廃棄物 } \\
\text { の発生量の削減 }\end{array}$ & $\begin{array}{l}\text { 単位床面積当り発生量 } \\
\text { ○○ } \mathrm{kg} \text { 以下 (建築工事 } \\
\text { のみ) }\end{array}$ & 0 & 0 & 0 & $\begin{array}{l}\text { 新規工事完成物件のみ対象 } \\
\text { 目標は、規模・用途により変化 }\end{array}$ & 0 \\
\hline 4 & $\begin{array}{l}\text { 熱帯材型枠使用 } \\
\text { 量の削減 }\end{array}$ & $\begin{array}{l}\text { 前年比 } \bigcirc \bigcirc \% \text { 削減（施 } \\
\text { 工面積） }\end{array}$ & 0 & $\triangle$ & $\Delta$ & $\begin{array}{l}\text { 積算段階で把握可能であるが、 } \\
\text { 専門会社に一任している為、M } \\
\text { ドリグ゙困難 }\end{array}$ & $\triangle$ \\
\hline 5 & 工事騒音の抑制 & $\begin{array}{l}\text { 苦情件数の前年比 } \\
\bigcirc \% \text { 削減 }\end{array}$ & 0 & $\triangle$ & $\Delta$ & $\begin{array}{l}\text { 分かりやすい指標 } \\
\text { 対策実施するも目標達成不明 } \\
\text { 工事特性で苦情件数の変化大 }\end{array}$ & $\triangle$ \\
\hline 6 & 工事振動の抑制 & $\begin{array}{l}\text { 苦情件 数の前年比 } \bigcirc \\
\text { ○\%削減 }\end{array}$ & 0 & $\triangle$ & $\triangle$ & 同上 & $\triangle$ \\
\hline 7 & 水質污濁の防止 & $\begin{array}{l}\text { 自主基準值を超える件 } \\
\text { 数 } 0 \text { 件 (Ph. SS) }\end{array}$ & $\triangle$ & O & 0 & $\begin{array}{l}\text { 明確な指標 } \\
\text { 設定レベル等によっては、コ忆運 } \\
\text { 用面に影響大 }\end{array}$ & 0 \\
\hline 8 & 地盤沈下の防止 & $\begin{array}{l}\text { 自主基準値を超える件 } \\
\text { 数 } 0 \text { 件 (変位) }\end{array}$ & $\triangle$ & 0 & 0 & & 0 \\
\hline
\end{tabular}

$\bigcirc:$ 適切 $\triangle:$ 十分でない $\times:$ 不適切

現状では、施工者が施工の段階で本体構造物の形状を変更することは一般に許されておらず、たとえ優れ た提案であっても設計へのフィードバックが困難な状況にある。建設業における新たな契約形態であるV E やP F I などの適用により、より自主的判断による決定が可能となる状況がうまれつつあるが、現場での状 況に応じて、設計を適宜変更できるようなシステム作りが必要であり、これが施工段階における環境パフォ ーマンスの向上につながるものと考えられる。

また、具体的指標としては、まず、取り組むべきは建設廃棄物（副産物）への対応である。この点につ いては、現在、マニフェスト制度の導入により、排出先と廃棄場所までの追跡が可能となっているが、さら に、廃棄の種類やリサイクルによって評価を指標化することが重要である。

\section{4. 評価結果に基づく継続的な環境パフォーマンスの改善}

\section{1 システムの改善}

MP I は、EMSを運用している企業ではシステムの継続的改善をするための一定の評価基準と一つとし て見なすことができる。システムを全体評価するためには、やはり明確な判断基準等を設け、分析する必要 があろう。しかし、現状では前述したように建設業の認証取得は緒についたばかりであり、システムの評価 は早計ではないかと思われる。つまり、内部環境監查や第 3 者審査によって出された指摘事項が是正され、 各社とも E M S の運用が進んでいく段階で、より具体的な指標が設定され効果的なシステムの推進ができる 
のではないかと思われる。特に、内部環境監査は、システムが有効に機能するために、潜在的な問題点を見 つけ出し改善策を打ち出す機会と捉え、積極的に活用するべきであろう。

\section{2 目的・目標の改善方法とその事例}

システムの見直しにおける「妥当性:adequacy」とは、(1)目的・目標の達成情況や重要度、(2)法規制等の 改廃の対応情況、(3)社会情勢や利害関係者の関心事への対応などで合目的・目標かを評価することである。 こうした指標を考慮し、適切な環境目的・目標を設定し、運用・評価することがシステムの継続的改善につ ながる。こうした観点から、表 2 に環境目的・目標の見直しへの対応方法と事例を以下に述べる。

表 2 目的・目標の見直し方法とその事例

\begin{tabular}{|c|c|}
\hline 見直し方法 & 事 例 \\
\hline 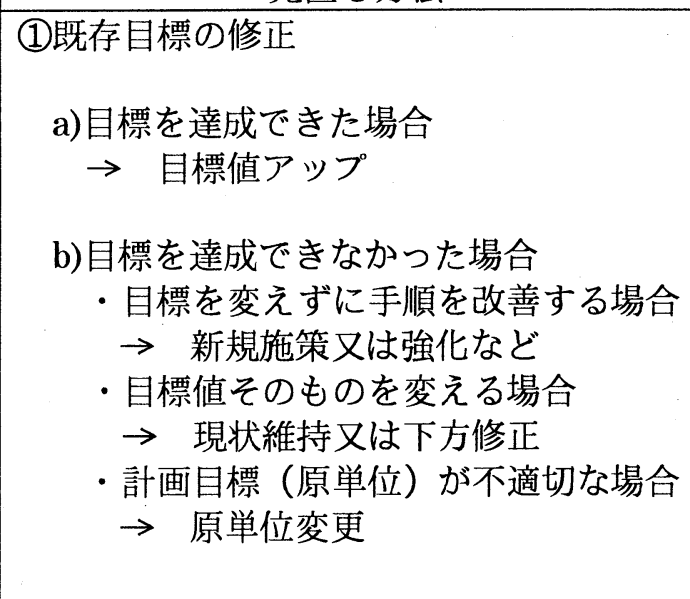 & 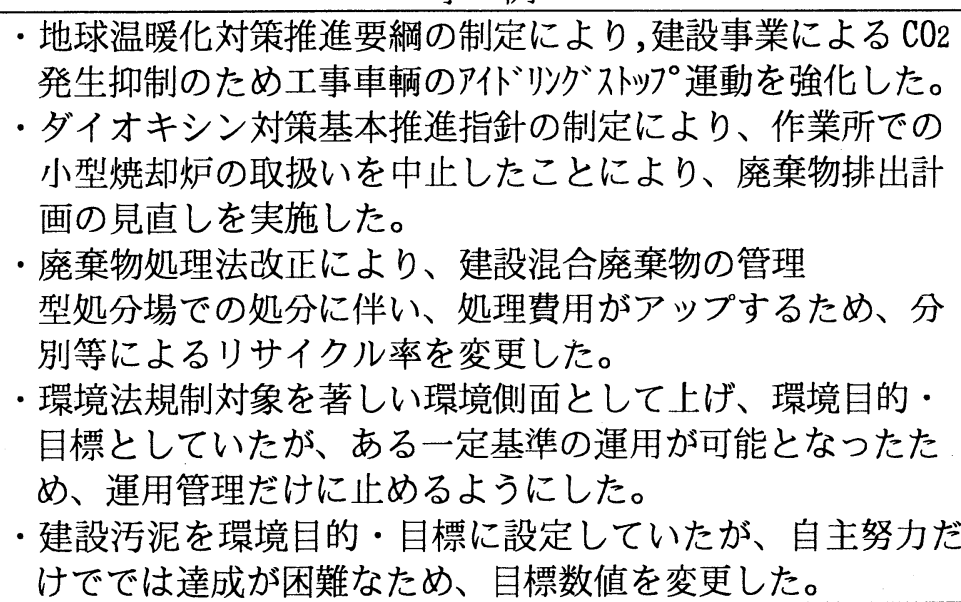 \\
\hline $\begin{array}{l}\text { (2)既存目標の削除 } \\
\text { a)これ以上改善できない場合 } \\
\text { b)不適切な目標であった場合 } \\
\text { c)代替方法で対応可能な場合 }\end{array}$ & 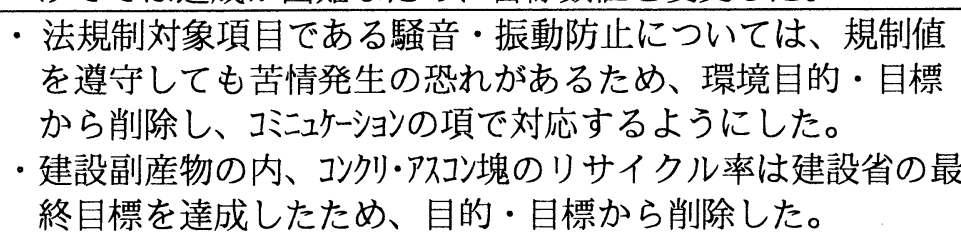 \\
\hline $\begin{array}{l}\text { (3)新規目標の追加 } \\
\text { a)周辺環境の変化 } \\
\text { b)利害関係者の関心事 }\end{array}$ & $\begin{array}{l}\text { ・土壌污染防止については、当社の污染浄化技術を開発し、 } \\
\text { 実施評価できるようになったために、新たに目的・目標に } \\
\text { 設定した。 } \\
\text { ·発注者が、I S O } 14001 \text { 認証取得により河川環境の保全の } \\
\text { 一環として法規制を上回る排水基準を要求してきたため、 } \\
\text { 新たに環境目的・目標に設定した。 }\end{array}$ \\
\hline
\end{tabular}

\section{5.まとめ}

以上、環境パフォーマンスの評価の一例を述べたが、あくまで当初どのように目的・目標を設定したかが 重要であることはいうまでもない。環境目的を設定する際には、著しい環境側面について、技術上、財政上、 運用上、事業上、利害関係者等の要求をいかに考慮して何から優先的に取り組むのかを明確にし、必要な経 営資源を投入するべきであろう。また、システムの見直しをする際には、特にシステムの実施状況や社会的 動向などを踏まえ、重要度に応じた管理をしていくことが継続的改善につながるもものと思われる。

最後に、環境パフォーマンスの改善策を費用との対比で評価する環境会計を導入し、効果的な環境保全対 策を行えることにより、E C Iへの貢献スピードも飛躍的に向上するのではないかと思われる。 